\title{
ORGANISMOS GENETICAMENTE MODIFICADOS: POR UMA OBEDIÊNCIA AOS DITAMES CONSTITUCIONAIS E À LEGISLAÇÃO CONSUMERISTA
}

\section{GENETICALLY MODIFIED ORGANISMS: FOR AN OBEDIENCE TO CONSTITUTIONAL DICTATES AND CONSUMERIST LEGISLATION}

\author{
Rosane Beatris Mariano da Rocha Barcellos Terra ${ }^{1}$ \\ Maria Paula da Rosa Ferreira ${ }^{2}$
}

\begin{abstract}
Resumo
Considerando o desenvolvimento da engenharia genética, analisou-se a respeito dos organismos geneticamente modificados pelo viés constitucional e legislativo. Assim sendo, questionou-se o tratamento dos ditames constitucionais e consumeristas quanto à contemplação da complexidade envolvente dos transgênicos, espécie de OGM. Para tanto, analisou-se o sistema de aprovação dos produtos transgênicos, assentado na abordagem quanto ao princípio da precaução, a necessidade dos estudos prévios de impacto ambiental e os potenciais riscos ambientais e à saúde humana. Ademais, destacou-se o direito à informação, relacionado com a rotulagem de produtos transgênicos. Juntamente a esta temática, indagouse o Projeto de Lei 4.148/2008, o qual tem a finalidade de mudar o paradigma da legislação no que se refere à rotulagem. Aplicou-se o método de abordagem dedutivo e o método de procedimento monográfico. À vista disso, inferiu-se que ainda não existem certezas científicas quanto às consequências do consumo de OGMs, assim como se observou a falha de uma ampla publicidade de estudos dos impactos que podem advir do uso desses organismos. Isso posto, averiguou-se que o consumo e comercialização de OGMs fere as garantias constitucionais e legais referentes à saúde, alimentação, segurança alimentar e meio ambiente ecologicamente equilibrado.
\end{abstract}

Palavras-chave: Direito à informação. Modificação genética. Organismos geneticamente modificados. Segurança Alimentar. Transgênicos.

\begin{abstract}
Considering the development of genetic engineering, was analyzed about the genetically modified organisms by constitutional and legislative bias. Faced with this, the treatment of constitutional and consumerist dictates was questioned about contemplation of the transgenic complexity, specie of GMOs. Therefore, was analyzed the approval system for transgenic products, based on the precautionary principle approach, the need for previous environmental impact studies and the potential environmental and human health risks. Moreover, was highlighted the right to information, related to the labeling of transgenic products. Together

\footnotetext{
${ }^{1}$ Doutora em Direito pela Universidade de Santa Cruz do Sul - UNISC. Professora do Centro Universitário Franciscano - UNIFRA, onde também atua como pesquisadora. Coordenadora e professora de PósGraduação Lato Sensu em Direito e em Auditoria e Controladoria pelo Centro Universitário Franciscano UNIFRA. Integrante do Comitê de Avaliação do Seminário de Iniciação Científica (SIC) pelo Centro Universitário Franciscano - UNIFRA. Integrante do Comitê do Seminário de Ensino Pesquisa e Extensão SEPE - do Centro Universitário Franciscano - UNIFRA. Integrante do Grupo de Pesquisas e Estudos Teoria Jurídica no Novo Milênio, do curso de Direito da UNIFRA. E-mail: rosanebterra@yahoo.com.br

${ }^{2}$ Mestranda em Direito pela Universidade Federal de Santa Maria - PPGD/UFSM. Integrante do Grupo de Pesquisa em Propriedade Intelectual na Contemporaneidade (GPPIC), da Universidade Federal de Santa Maria (UFSM). E-mail: mariapauladarosa@hotmail.com
} 
with this theme, was inquired the Draft Law 4,148 / 2008, which has the purpose, to change the paradigm of legislation with regard to labeling. Was applied the approach method deductive, the procedure method monographic. In view of this, has been inferred that there aren't scientific certainties about the consequences of the consumption of GMOs, as was observed the failure of a broad publicity of impact studies that may arise from the use of these organisms. That put, it was found that consumption and commercialization de OGMs violates constitutional and legal guarantees relating to health, food, food safety and ecologically balanced environment.

Keywords: Food Security. Genetically modified organisms. Modification genetically. Right to information. Transgenics.

\section{INTRODUÇÃO}

O presente artigo defronta-se com a problemática dos organismos geneticamente modificados por meio de uma averiguação referente ao cumprimento das previsões constitucionais e legais correlatas à temática. Adotou-se uma abordagem quanto às premissas constitucionais e consumeristas em relação ao princípio da informação, respaldado em uma análise principiológica e o respectivo tratamento legal em âmbito nacional.

Nessa ordem de raciocínio, esta produção acadêmica é construída com base em dois tópicos, sendo que o primeiro se destina a abordar quanto aos organismos geneticamente modificados, com uma conceituação e caracterização dos $\mathrm{OGMs}^{3}$, adotada cientificamente e um histórico das autorizações dos transgênicos no país, assim como, quanto aos eventuais riscos aos consumidores e ao meio ambiente decorrente do uso de transgênicos.

O tópico seguinte refere-se ao direito à informação, observando-se este direito a partir da natureza transgênica dos produtos ofertados. Neste ponto, parte-se de uma avaliação quanto aos apontamentos constitucionais e os tratamentos legislativos. Além disso, trata-se sobre a imprescindibilidade do princípio da precaução e da indispensabilidade do estudo prévio de impacto ambiental. Neste seguimento, verificam-se questões de vultosa relevância a respeito da rotulagem de produtos que contenham transgenia.

Neste artigo, adota-se o que se encontra previsto em lei quanto aos organismos geneticamente modificados, utilizando-se o entendimento de que o gênero abarca a espécie. Portanto, considera-se que o uso do termo OGM alcança aos transgênicos. Assim, empregam-se ambos os termos no tratamento da temática.

\footnotetext{
${ }^{3}$ OGMs significa organismos geneticamente modificados.
} 
Para tanto, a metodologia adotada será o método de abordagem dedutivo, o qual parte-se da lógica Aristotélica, apoiado em premissas consideradas como verdadeiras a fim de ser obtida a uma conclusão lógica, no tocante ao direito à informação quanto ao uso e à comercialização de organismos geneticamente modificados frente a uma exposição de perigos imprevisíveis.

Como método de procedimento, empregou-se o monográfico, uma vez que se perscrutou uma pesquisa bibliográfica ampla e satisfatória a respeito do tema proposto, no intuito de ser estudada a necessidade de propagação de informações e alertas à população a respeito dos perigos e danos que podem ser gerados a partir da utilização de produtos transgênicos, sem a devida informação do que é ofertado na rede de consumo. Por conseguinte, utilizou-se o procedimento de análise bibliográfica e técnica de coleta de dados pela produção de fichamentos e resumos expandidos de contribuições teóricas já existentes sobre a presente temática de abordagem. Por meio dos métodos empregados, buscou-se gerar uma orientação, pontual, aos indivíduos sobre os direitos fundamentais enquanto consumidores na condição de (hiper)vulneráveis.

Ademais, o presente artigo encontra-se coadunado com a linha de pesquisa de Direito Ambiental, conflitos socioambientais e riscos ambientais, visto que um estudo direcionado a questões de meio ambiente bem como sustentabilidade, relacionados com a questão consumerista, estabelecem importantes ferramentas de atuação do Estado e sociedade para que sejam conhecidos e devidamente estudados os princípios norteadores da relação, implementação e utilização ou não de transgênicos pelos indivíduos.

\section{ORGANISMOS GENETICAMENTE MODIFICADOS: UMA FALA INAUGURAL}

Por volta da década de 70, estudos científicos quanto à transferência genética do DNA de uma espécie para o DNA de outra tiveram prelúdio, o que foi considerado uma grande conquista científica, tendo em vista que diversos organismos poderiam ser providos de genes não naturais e, assim, serem introduzidas características diferentes das previstas em suas espécies ${ }^{4}$.

Desse modo, diversas combinações genéticas já foram efetuadas cientificamente, tal como a modificação genética de sementes, que alteram atributos das plantas cultivadas. Porém,

\footnotetext{
${ }^{4}$ ROBIN, 2008.
} 
a partir deste avanço científico, emerge uma relevante preocupação quanto aos prováveis efeitos que podem advir do consumo de alimentos modificados geneticamente.

Sendo assim, observa-se que se está diante de incertezas quanto aos prováveis prejuízos da adoção e consumo de OGMs. Portanto, é de fundamental pertinência a abordagem dos tópicos a seguir expostos, que buscam apontar aspectos relevantes quanto aos organismos geneticamente modificados.

\section{Conceituação e caracterização dos ogms na conjuntura atual}

No presente artigo, não se pode deixar de iniciar a temática pela conceituação de organismo geneticamente modificado (OGM), eis que a partir deste preâmbulo conceitual será possível se estabelecer os marcos relevantes que deram razão ao estudo em específico. Assim sendo, o referido conceito está estabelecido na legislação brasileira, desde 1945, com a lei $8.974^{5}$ - antiga lei de Biossegurança, que fora revogada pela Lei no $11.105 / 2005^{6}$ - atual Lei de Biossegurança, a qual estabelece que, para efeitos legais, conforme o artigo 3 , inciso $V$, organismo geneticamente modificado (OGM) é "organismo cujo material genético - ADN/ARN ${ }^{7}$ tenha sido modificado por qualquer técnica de engenharia genética".

Porém, ressalta-se que esta lei não consegue alcançar a eficiência e a especificidade que se requer para a devida compreensão do assunto. Sendo assim, destaca-se que o conceito de transgênico não pode ser confundido com OGM. Desse modo, cabe apontar os ensinamentos de Zanini:

Seja como for, nossa legislação não foi além dos organismos geneticamente modificados, ou melhor, nada mencionou acerca dos transgênicos, que muitas vezes são tratados simplesmente como sinônimos de OGMs. Os transgênicos, entretanto, não são sinônimos de OGMs, pois, em realidade, os transgênicos são espécies de OGMs.

Desta maneira, ousa-se dizer que a melhor opção é a adoção do que está disposto em lei quanto aos organismos geneticamente modificados. No entanto, tendo em vista que o gênero abarca a espécie, os transgênicos estariam sendo alcançados pela referência aos OGMs. “Ambas as definições remetem às transformações que tenham origem em técnicas de engenharia genética que produzem moléculas de DNAr [DNA recombinante]"9.

\footnotetext{
${ }^{5}$ BRASIL, 1995.

${ }^{6}$ BRASIL, 2005.

${ }^{7}$ ADN significa ácido desoxirribonucleico, mesmo que DNA, responsável pela informação genética dos seres vivos e ARN significa ácido ribonucleico, o qual também controla a atividade celular.

${ }^{8}$ ZANINI, 2009, p. 3-4.

${ }^{9}$ AYALA, 2009, p. 111.
} 
A engenharia genética é a tecnologia que trabalha com a produção de produtos transgênicos, a qual recebe investimentos consideráveis provindos das empresas fabricantes de agrotóxicos, que, não raramente, possuem interesses na aprovação de artefatos modificados geneticamente, pois, correntemente, o cultivo de transgênicos está associado à utilização de venenos agrícolas.

No que tange a criação, pela engenharia genética, de transgênicos, destaca Smith ${ }^{10}$ que:

[...] o processo de criar um transgênico pode produzir mudanças consideráveis no funcionamento natural do DNA da planta. Os genes nativos podem sofrer mutações, ser excluídos, permanentemente desativados ou ativados, e centenas podem modificar seu nível de expressão. O gene inserido pode se tornar truncado, fragmentado, misturado com outros genes, invertido ou multiplicado, e a proteína transgênica que ele produz pode ter características não intencionais com perigosos efeitos colaterais. [...] Além das mudanças não intencionais do DNA, há risco à saúde devido a outros aspectos dos cultivos transgênicos. Quando um transgene começa a funcionar na nova célula, por exemplo, ele pode produzir proteínas que são diferentes daquela intencionada. A sequência de aminoácidos pode estar errada, o formato da proteína pode ser diferente e as ligações moleculares podem tornar a proteína prejudicial. [...] Outra questão a considerar é que os genes inseridos podem se transferir do alimento para as bactérias do intestino e os órgãos internos. Estudos em animais demonstram que o DNA ingerido pode percorrer todo o corpo, até mesmo para um feto, via placenta. Transgenes de cultivos GM fornecidos a animais foram encontrados no sangue, fígado, baço e rins. O único teste publicado feito com seres humanos alimentados com transgênicos verificou que o material genético inserido na soja GM transfere-se para o DNA de nossas bactérias intestinais.

Devido a esta problemática, é considerável a preocupação global quanto à adoção e o consumo de produtos transgênicos, tendo em vista a insegurança presente na utilização de OGMs, principalmente no que se refere à saúde de toda a população.

Como consequência disso, observa-se a presença de um lobby bastante forte para a promoção de transgênicos, assim como estabelecido por Smith ${ }^{11}$ :

[...] em todos os lugares, as aprovações têm por base que os desenvolvedores da tecnologia fazem estudos de segurança de seus próprios cultivos. A pesquisa não precisa ser publicada e a maior parte é mantida em segredo sob o disfarce de "informações comerciais confidenciais". Poucos dados estão disponíveis para escrutínio público (com grifos no original).

Dessa forma, percebe-se a tentativa das empresas de biotecnologia de se esquivarem da devida publicidade que merece os estudos quanto aos prováveis efeitos da adoção de dada

\footnotetext{
${ }^{10}$ SMITH, 2009, p. 3-4.

${ }^{11}$ SMITH, 2009, p. 2.
} 
tecnologia de modificação genética. Além disso, é observada a utilização de "formas criativas de evitar encontrar problemas"12 por parte das indústrias produtoras de OGMs que financiam os estudos quanto à segurança dos transgênicos. Assevera, também, Smith ${ }^{13}$ que infelizmente a segurança está a cargo da indústria, que, muitas vezes, desenvolve testes de cultivos transgênicos aquém do padrão exigido cientificamente.

No mesmo sentido, expõe o Grupo de Ciência Independente ${ }^{14}$ que:

[...] os cultivos de transgênicos são inaceitáveis porque não são seguros. Têm sido introduzidos sem as necessárias salvaguardas e avaliações de segurança, através de um sistema de regulamentação profundamente defeituoso, baseado no princípio da "equivalência substancial", cujo propósito é dar rápida aprovação aos produtos, em vez de realizar uma avaliação séria de sua segurança (com grifos no original).

Diante do exposto, observa-se que tem sido utilizada uma das tecnologias mais perigosas do mundo sem os devidos estudos bem como sem a publicidade quanto aos potenciais efeitos nocivos aos seres humanos, ocorrendo, portanto, uma aprovação de fachada que recebe influência e manipulação das indústrias de biotecnologia, que buscam promover benefícios próprios, ignorando-se os interesses dos consumidores.

São as transnacionais gigantes do setor da agroquímica, indústria farmacêutica e de processamento de alimentos que dominam a pesquisa e os mercados. [...] A criação e venda bem-sucedida de sementes resistentes aos herbicidas de uma determinada marca vão resultar em mais concentração econômica no mercado da agroindústria, aumentando o poder de mercado das companhias transnacionais ${ }^{15}$.

Desse modo, atenta-se que as grandes corporações têm o intuito de controlar as sementes transgênicas e, consequentemente, efetuarem o controle sobre a alimentação das pessoas. Portanto, é de expressiva relevância a breve análise a seguir quanto ao uso e comercialização dos organismos geneticamente modificados no Brasil.

\section{Breve resgate histórico dos ogms}

Diante das controvérsias existentes em relação aos organismos transgênicos, referendase que o cultivo e a comercialização começaram a ser alçados no início de 1998, "quando a

\footnotetext{
12 Eles alimentam animais mais velhos ao invés de jovens, mais sensíveis; mantêm tamanho muito pequeno de amostras para alcançar a significância estatística necessária para prova em estudos científicos; diluem o componente transgênico na ração; cozinham demais as amostras; comparam resultados com controles irrelevantes; escolhem métodos de detecção obsoletos e de baixa sensibilidade; limitam a duração dos testes de alimentação; e chegam até a ignorar as mortes e doenças dos animais. SMITH, 2009, p. 3.

${ }^{13}$ SMITH, 2009, p. 3-4.

${ }^{14}$ GRUPO DE CIÊNCIA INDEPENDENTE, 2004, p.105.

${ }^{15}$ SHIVA, 2003, p. 136, 142-144.
} 
Comissão Técnica Nacional de Biossegurança emitiu parecer à empresa multinacional Monsanto autorizando o plantio da soja transgênica $R R^{\prime 16}$. A autora destaca que foi inobservado o preceito constitucional - previsto no artigo 225 , parágrafo 10, IV ${ }^{17}$ - que exige o estudo prévio de impacto ambiental.

Ademais, Ferreira ${ }^{18}$ aborda que por meio da edição da Medida Provisória (MP) № 113/2003, a qual tratava a respeito da comercialização da produção de soja da safra de 2003, restaram incluídas as sementes transgênicas que foram introduzidas de forma ilegal no Brasil. Merece destaque, portanto, que a safra de 2003 foi excluída das restrições e das previsões quanto à segurança biológica estabelecidas na Lei no 8.974/1995. Esta MP foi posteriormente convertida na Lei $n=10.688 / 2003^{19}$, razão pela qual o texto das medidas foram incorporadas por este instrumento legal devidamente referendado em nota de rodapé. Salienta-se, a título de ratificação de relevância, que a supramencionada lei veio estabelecer normas para a comercialização da produção de soja da safra de 2003.

Este fato demonstra a "manifestação máxima da irresponsabilidade organizada no contexto da atual política ambiental brasileira" ${ }^{20}$. Assevera-se, ademais, que o mesmo ocorreu com a produção da soja transgênica do ano de 2004, que se efetuou por meio da Medida Provisória no 131/2003, que tratou a respeito da utilização da soja transgênica da safra de 2004 , convertida na Lei no $10.814 / 2003^{21}$, a qual estabeleceu normas para o plantio e comercialização da produção de soja da safra de 2004, e do ano de 2005, por meio da Medida Provisória no 223/2004, que se dedicou a abordar a respeito da utilização da soja transgênica da safra de 2005, sendo posteriormente aprovada a redação do Projeto de Lei no 2.401/2003, oportunamente transformado na Lei no 11.105/2005, que é a atual Lei de Biossegurança.

\footnotetext{
16 FERREIRA, 2010, p. 105.

17 Art. 225 - Todos têm direito ao meio ambiente ecologicamente equilibrado, bem de uso comum do povo e essencial à sadia qualidade de vida, impondo-se ao Poder Público e à coletividade o dever de defendê-lo e preservá- lo para as presentes e futuras gerações. § 10 Para assegurar a efetividade desse direito, incumbe ao Poder Público: IV - exigir, na forma da lei, para instalação de obra ou atividade potencialmente causadora de significativa degradação do meio ambiente, estudo prévio de impacto ambiental, a que se dará publicidade. BRASIL, 1988.

18 FERREIRA, 2010, p. 106.

${ }^{19}$ BRASIL, 2003.

${ }^{20}$ LEITE; AYALA, 2004, p. 181-182.

${ }^{21}$ BRASIL, 2003.
} 
À vista disso, quanto à liberação das plantas transgênicas, merece destaque, também, a exposição da Presidente do Conselho Nacional de Segurança Alimentar e Nutricional (CONSEA), Pacheco ${ }^{22}$ :

É importante salientar que a grande maioria das plantas transgênicas liberadas recebeu votos contrários devidamente fundamentados dos representantes dos Ministérios da Saúde (MS), do Meio Ambiente (MMA) e do Desenvolvimento Agrário (MDA), além de representantes da sociedade civil, pois avaliaram que essas plantas não deveriam ou não estariam prontas para ser liberadas. [...] Apesar de o Brasil ser signatário do Protocolo de Cartagena de Biossegurança, da Convenção sobre Diversidade Biológica da Organização (CDB) das Nações Unidas, as informações submetidas pelas empresas requerentes de liberação de seus produtos ao órgão competente, frequentemente contemplam estudos realizados em um número bastante reduzido de localidades e de repetições (há casos de apenas 2 ou 3 municípios) e, em regra, desconsideram biomas inteiros. Nota-se que a avaliação de risco não é feita de forma independente e que as plantas transgênicas comercializadas no país foram aprovadas quase que exclusivamente com base em testes de avaliação de eficácia agronômica, sem os estudos sobre os riscos à segurança ambiental recomendados pelo Protocolo de Cartagena, violando o princípio da precaução.

Por conseguinte, aponta-se que as liberações destes artefatos tendem a ocorrer devido a decisões políticas e, não, científicas, como também tendem a serem ignorados aspectos relevantes quanto ao estudo prévio de impacto ambiental e ao princípio da precaução, o que demonstra uma afronta ao que se encontra previsto na Constituição Federal e na Lei de Biossegurança.

Outrossim, no mesmo sentido explanou da Silva Augusto ${ }^{23}$, na Notificação de desligamento da Comissão Técnica Nacional de Biossegurança e declaração de motivos, no ano de 2007:

Em minha opinião, a lei 11.105/2005 que criou a CTNBio fez um grande equívoco ao retirar dos órgãos reguladores e fiscalizadores os poderes de analisar e decidir sobre os pedidos de interesse comercial relativos às plantas transgênicas para alimentação humana e animal, especialmente sobre as liberações comerciais. [...] A CTNBio está constituída por pessoas com título de doutorado, cuja maioria se constitui em especialistas em biotecnologia e interessados diretamente em seu desenvolvimento. Há poucos especialistas em biossegurança capazes de avaliar riscos para a saúde e para o meio ambiente. [...] Na prática da maioria, é desconsiderado o Princípio da Precaução, um dos pilares mais importantes do Protocolo de Biossegurança de Cartagena que deve nortear as ações políticas e administrativas dos governos signatários. O que vemos na prática cotidiana da CTNBio são votos pré-concebidos e

\footnotetext{
${ }^{22}$ CONSEA, 2014.

${ }^{23}$ AUGUSTO apud SMITH, 2009, p. XVII - XVIII.
} 
uma série de artimanhas obscurantistas no sentido de considerar as questões de biossegurança como dificuldades ao avanço da biotecnologia.

No que se refere à Comissão Técnica Nacional de Biossegurança - CTNBio- foi esta criada em 1995. Trata-se de um órgão vinculado ao Ministério de Ciência e Tecnologia, responsável pelas autorizações e aprovações quanto à utilização de transgênicos no país. No entanto, o que se percebe são análises feitas pela CTNBio com interesses comerciais se sobrepondo aos interesses de biossegurança. Podendo ser citado, a título exemplificativo, a Medida Provisória 327/2007 que fora convertida na Lei $11.460 / 2007^{24}$, que teve a finalidade de diminuir a área livre do plantio de transgênico no entorno de unidades de conservação.

Portanto, é de extrema relevância o que apresenta Smith ${ }^{25}$ quanto à aprovação da utilização de transgênicos no Brasil:

ANVISA e IBAMA fizeram análises detalhadas dos primeiros milhos liberados e concluíram que as empresas forneceram dados insuficientes e falhos, que não permitiriam a conclusão da CTNBio sobre a segurança dos produtos [...] Até o início de 2009, a CTNBio liberou quatro variedades de algodão transgênico, uma de soja e seis de milho. Todas foram autorizadas com base em estudos apresentados pelas próprias empresas e dispensando a realização dos estudos de impacto ambiental e estudos independentes sobre riscos à saúde humana, o que é especialmente grave para soja e milho, ambos ingredientes presentes na grande maioria dos alimentos industrializados.

Dessa forma, observa-se que a aplicação e autorização de produtos modificados geneticamente, sabendo-se que os efeitos colaterais desta adoção são imprevisíveis, os quais, em muitos casos, sequer estão sendo avaliados pela CTNBio, refletem uma forma irresponsável e muito perigosa de utilização de organismos transgênicos. Assim, não é concebível que as estratégias de marketing, que têm por considerar os alimentos transgênicos como seguros, se sobreponham ao direito à informação bem como ao direito fundamental à saúde e à alimentação.

Na sequência, impõe-se relevante apontar os eventuais riscos aos consumidores e ao meio ambiente quanto aos organismos geneticamente modificados.

\footnotetext{
24 BRASIL, 2007.

${ }^{25}$ SMITH, 2009, p. XXII.
} 


\section{Eventuais riscos aos consumidores e ao meio ambiente pelo uso de OGMS}

No que tange aos eventuais riscos, o questionamento que permeia a inquietação assenta no seguinte ponto: o que os organismos geneticamente modificados podem acarretar aos consumidores e ao meio ambiente? Neste sentido, destaca-se o que referencia Smith ${ }^{26}$ :

[...] De fato, os cultivos transgênicos são inerentemente perigosos e podem ser responsáveis pelo desdobramento de um desastre de saúde. O que é estarrecedor, além disso, é a ausência de pesquisa indo atrás dessas crescentes evidências e o contínuo menosprezo a reações adversas sérias. Isso demonstra uma temerária desconsideração à segurança, tanto por parte da indústria de biotecnologia quanto pelos órgãos governamentais encarregados de regulamentar e de garantir a segurança dos produtos.

Diante do explanado, compreende-se que os organismos geneticamente modificados são exemplo de risco potencial aos seres humanos, principalmente no que se refere à saúde e à segurança alimentar.

No mesmo sentido, é abordado pelo Instituto Brasileiro de Defesa do Consumidor que:

[...] muitos estudos e evidências relacionam os transgênicos a impactos em nossa saúde, no meio ambiente e na agricultura. A questão é tão grave que a Anvisa - Agência Nacional de Vigilância Sanitária (Ministério da Saúde) e o Ibama - Instituto Brasileiro do Meio Ambiente e dos Recursos Naturais Renováveis (Ministério do Meio Ambiente) foram contrários à decisão da CTNBio - Comissão Técnica Nacional de Biossegurança de liberar os milhos transgênicos Liberty Link, da Bayer; MON810, da Monsanto; e Bt 11, da Syngenta. Mas o Conselho de Ministros (CNBS) desconsiderou os argumentos técnicos dos órgãos do Ministério da Saúde e do Ministério do Meio Ambiente e apoiou a liberação dos milhos. Hoje já existem no Brasil soja e milho transgênicos autorizados para consumo. Portanto, para evitar o seu consumo, é muito importante buscar a informação no rótulo dos alimentos ${ }^{27}$.

No entanto, a Academia Nacional de Ciências dos Estados Unidos divulgou, no dia 17 de maio de 2016, um vasto relatório abordando que os transgênicos não fazem mal à saúde, no qual afirmou não haver direta relação do consumo de OGMs com obesidade, diabetes, câncer e autismo e que não causam problemas ambientais. Segundo restou divulgado na mídia nacional e internacionalmente, aproximadamente 50 (cinquenta) pesquisadores avaliaram durante dois anos mais de 900 (novecentos) estudos a respeito dos transgênicos ${ }^{28}$.

Porém, o que se deve atentar é que esta organização serve de conselheira do governo americano, desde 1863. Dessa forma, cabe analisar alguns aspectos que são adotados pelos

\footnotetext{
${ }^{26}$ SMITH, 2009, p. 6-7.

27 IDEC, 2010, p. 3.

${ }^{28}$ NATIONAL ACADEMIES OF SCIENCES, ENGINEERING, AND MEDICINE, 2016.
} 
EUA quanto ao cultivo de transgênicos, sendo estes: 1) Dada pesquisa reiterou o princípio da equivalência substancial, já adotado pelos Estados Unidos, que fundamentou e ainda fundamenta o consumo destes alimentos internamente; 2) Em 1992, especialistas técnicos da Agência para Alimentos e Drogas dos Estados Unidos (FDA) alertaram que a engenharia genética levaria a riscos diferentes, comparado ao melhoramento tradicional de plantas, sendo alertados, assim, seus superiores quanto a esta preocupação dos efeitos colaterais imprevisíveis e de difícil constatação que poderiam ser ocasionados à população ${ }^{29}$. Estes cientistas exigiram estudos longitudinais aos responsáveis pela FDA, "para se prevenir contra possíveis alergias, toxinas, novas doenças e problemas nutricionais" ${ }^{30}$. Contudo, as observações dos cientistas foram mantidas em sigilo e, somente, revelados os arquivos internos por meio de uma ação judicial, sete anos depois. Os requerimentos dos especialistas foram ignorados pela FDA. Posteriormente, foi divulgado o motivo da falta de atenção dada às requisições solicitadas:

[...] a FDA estava seguindo ordens da Casa Branca para promover cultivos GM e que Michael Taylor, ex-advogado da Monsanto e mais tarde seu vice-presidente, foi colocado na FDA para supervisionar o desenvolvimento do programa. Com Taylor como responsável, os alertas dos cientistas foram ignorados e negados ${ }^{31}$.

Assim, questiona-se, de igual maneira, o recente estudo, publicado neste ano, quanto aos transgênicos, no sentido de ser observada a utilização, pelos EUA, de formas criativas de se evitar problemas com a comercialização dos transgênicos, visando-se o lucro em primeiro lugar, como restara demonstrado no acontecimento supramencionado. Algo que ainda se torna intrigante trata-se a respeito de que a publicação desta pesquisa ocorreu "no momento em que o Congresso norte-americano - que fundou a instituição - estuda tornar obrigatória a rotulagem de transgênicos" ${ }^{32}$. No mesmo sentido, o grupo de defesa ambiental Food \& Water Watch (FWW) publicou a pesquisa Under the Influence: the National Research Council and $\mathrm{GMOs}^{33}$, na qual demonstra que o Conselho Nacional de Pesquisa e a Academia Nacional de Ciências dos EUA recebem financiamentos milionários das indústrias de biotecnologia, tal como a Monsanto, DuPont e DowChemical. O que torna questionável os resultados demonstrados e publicados internacionalmente pela Academia Nacional de Ciências dos Estados Unidos.

Sendo assim, como contextualização referente ao cenário internacional, cita-se o tratamento dos transgênicos na União Europeia, que, em 2001, suspendeu o cultivo e

\footnotetext{
${ }^{29} \mathrm{SMITH}, 2009$, p. $1-2$.

30 SMITH, 2009, p. 1.

${ }^{31}$ SMITH, 2009, p. 2.

32 PRUPIS, 2016.

33 FWW, 2016.
} 
comercialização de produtos GM até que as devidas pesquisas e avaliações nas áreas de meio ambiente, saúde e segurança fossem efetivadas, de modo que pudessem esclarecer os riscos e efeitos dos OGMs na saúde humana, no cultivo de vegetal, no meio ambiente e na alimentação ${ }^{34}$. Destaca-se, assim, que a UE adota normas mais rigorosas de controle dos transgênicos referentes ao cultivo, produção, rotulagem e identificação, ${ }^{35}$ de forma que, a partir de outubro de 2015, 19 (dezenove) membros, dentre as grandes potências como Alemanha, França, Itália e parte do Reino Unido, optaram por banir o cultivo de alimentos transgênicos ${ }^{36}$.

Diante disso, defronta-se que ainda se está diante de uma carência de estudos científicos significativos com a adoção de critérios estatísticos necessários e adequados para obterem-se resultados que tragam provas robustas, por meio de métodos científicos de qualidade, quanto aos possíveis efeitos dos OGMs aos seres humanos e ao meio ambiente. Merece ser observado que, não raramente, foram negligenciados argumentos técnicos de extrema relevância a fim de se obter a aprovação e liberação de alimentos transgênicos para o consumo tanto no Brasil como no exterior.

A intoxicação que o uso constante e crescente de agrotóxicos pode causar ao ser humano é preocupante, segundo posicionamento de Nodari ${ }^{37}$ :

As tecnologias mais perversas do ponto de vista ambiental e da saúde humana são os agrotóxicos. [...] Esses produtos estão associados a diferentes tipos de câncer e outras doenças, como os males de Alzheimer ou Parkinson, a perturbações na reprodução humana, à dor física e mesmo à morte de seres vivos. Ao meio ambiente é praticamente impossível estimar com precisão os profundos efeitos adversos reais ou iminentes. Alterações na dinâmica de populações de organismos, altas taxas de mortalidade entre espécies e modificações nos processos ecológicos são apenas alguns dos impactos razoavelmente estudados.

Por conseguinte, verifica-se a direta relação entre o cultivo de transgênicos o e uso de agrotóxicos, bem como é de notável percepção o crescente aumento quanto à utilização destes venenos químicos que podem vir a acarretar efeitos imensuráveis decorrentes da contaminação não somente dos alimentos como também de todo um ecossistema que envolve água, ar, solo e a consequente infecção dos fatores bióticos que envolvem a fauna e a flora. Frente a tamanhas ameaças decorrentes do uso de agrotóxicos, citam-se dados de suprema relevância dentro do enfoque tratado:

\footnotetext{
${ }^{34}$ MOREIRA, 2001, p. 231.

${ }^{35}$ MOREIRA, 2001, p. 231.

36 NUNES, 2015.

${ }^{37}$ NODARI, 2010, p. XII.
} 
No Brasil são concomitantes o uso de agrotóxicos e o cultivo de plantas transgênicas. Somos, desde 2010, os campeões mundiais no uso de agrotóxicos, com uma média de mais de cinco quilos para cada brasileiro por ano. Esses dois crescimentos estão relacionados. Enquanto em 2001, no Brasil, se usou o equivalente a $2,7 \mathrm{~kg}$ de agrotóxicos por hectare cultivado, em 2010, foram cerca de $5 \mathrm{~kg}$. Houve um crescimento, no período, da área cultivada com soja e milho transgênicos. A relação entre o cultivo de transgênicos e o aumento do uso de agrotóxicos é notória, uma vez que várias plantas geneticamente modificadas aprovadas para comercialização no Brasil sofreram alteração para receber agrotóxicos. [...] Nesse processo haverá contaminação das águas, do ar, da chuva, dos alimentos, do leite materno, do sangue e da urina dos humanos e dos outros animais. Portanto, não existe uso seguro de agrotóxicos na agricultura ${ }^{38}$.

Para contribuir com o entendimento acima, citam-se, brevemente, colaborações de diversos pesquisadores que evidenciam riscos à saúde decorrentes de alimentos provindos de organismos geneticamente modificados:

I- Camundongos alimentados com batatas GM tiveram danos nos intestinos ${ }^{39}$;

II- Trabalhadores expostos ao algodão Bt desenvolveram reações de pele, olhos e trato respiratório superior ${ }^{40}$;

III- Produtores relatam que porcos e vacas tornaram-se estéreis devido ao milho transgênico ${ }^{41}$;

IV- Camundongos alimentados com soja transgênica Roundup Ready tiveram problemas nas células do fígado e no pâncreas ${ }^{42}$;

V- Camundongos alimentados com soja Roundup Ready tiveram alterações inexplicáveis nas células testiculares ${ }^{43}$;

VI- Ervilhas GM geraram uma resposta inflamatória de tipo alérgico em camundongos ${ }^{44}$;

VII- Alimentos GM podem criar doenças resistentes a antibióticos ${ }^{45}$;

VIII- Se genes Bt se transferirem, eles poderão transformar nossas bactérias intestinais em fábricas vivas de agrotóxicos ${ }^{46}$;

IX- Genes podem se transferir para bactérias na boca ou garganta ${ }^{47}$;

\footnotetext{
${ }^{38}$ CARNEIRO et al, 2015, p. 112-113.

${ }^{39}$ CARMAN, 2004, p. 82-93.

${ }^{40}$ GUPTA, 2005.

${ }^{41}$ MARKAVERICH, 2005.

${ }^{42}$ MALATESTA, 2002, p. 173-180.

43 GURAYA, 1987.

${ }^{44}$ PRESCOTT et al, 2005, p. 53.

45 LEWIS, 1995.

${ }^{46}$ DUGGAN, 2003, p. 159-166.
} 
X- Cultivos tolerantes a glufosinato podem produzir herbicidas dentro do intestino ${ }^{48}$;

XI- Cultivos tolerantes a herbicidas aumentam o uso de herbicidas e os resíduos em alimentos ${ }^{49}$;

XII- Cultivos resistentes a doenças podem promover novos vírus de plantas, os quais trazem riscos para humanos ${ }^{50}$;

XIII- Mulheres grávidas que comem alimentos GM podem colocar a prole em risco ${ }^{51}$.

Ainda, em relação aos efeitos causados ao meio ambiente, reputa-se de imperiosa contribuição o que aduz Ferreira:

Dentre os potenciais impactos comumente referidos pela doutrina, temse: o fluxo de genes, a transferência horizontal de genes, a formação de plantas daninhas e insetos invasores resistentes a pesticidas, as interferências causadas na microbiota do solo, a redução ou perda da diversidade biológica, a ameaça ao bem-estar dos animais e, por fim, os riscos alimentares. Cumpre mencionar que, muitas vezes, esses são aspectos que se relacionam, o que significa dizer que uma única causa pode provocar efeitos diversos e distintos, mas que se encontram interconectados ${ }^{52}$.

Diante dos preocupantes dados supracitados, são alarmantes os riscos iminentes a todos os seres vivos e ao meio ambiente. Desse modo, faz-se necessário que seja feita uma maior investigação científica a partir dos resultados das pesquisas publicadas de maneira esparsa, a fim de que, por meio de estudos a longo prazo, possam ser obtidas conclusões que melhor adequem a manipulação genética a uma forma confiável e promotora de um autêntico avanço à saúde e ao meio ambiente.

Em face disso, frente aos impactos ambientais que os produtos transgênicos podem causar bem como os riscos inerentes à produção, deve-se, sobretudo, se atentar à proteção ao ser humano, o qual deve ter assegurado o direito à alimentação, garantindo-se segurança alimentar e nutricional a todos os indivíduos de modo que tenham a dignidade assegurada e a proteção que Ihes é garantida pela Constituição Federal.

Nessa senda, cabe apresentar, a seguir, o conteúdo a respeito do direito básico do consumidor à informação eficaz quanto à natureza transgênica dos produtos ofertados.

\footnotetext{
47 DUGGAN, 2003, p. 159-166.

48 STEINBRECHER, 2002.

${ }^{49}$ BENBROOK, 2004.

50 DASGUPTA; GARCIA; GOODMAN, 2001, p. 491.

${ }^{51}$ FREESE; SCHUBERT, 2004.

52 FERREIRA, 2010, p 75.
} 


\section{DIREITO À INFORMAÇÃO: A BUSCA PELA EFICÁCIA}

Diante da tecnologia irreversível, que transforma geneticamente os organismos, observa-se que prováveis consequências extremas podem afetar à saúde humana e animal como também atingir de forma inquietante o meio ambiente.

Assim, é relevante ser abordado sobre o direito à informação aos consumidores de alimentos transgênicos. Tendo em vista os perigos imprevisíveis que o consumo de OGMs pode acarretar, é de grande magnitude que sejam expostas aos consumidores informações fidedignas tanto nos rótulos dos produtos transgênicos como também por meio da publicidade dos estudos realizados referentes aos efeitos à saúde humana, segurança alimentar e aos impactos ao meio ambiente.

Para tanto, é de grande monta ser observado os apontamentos constitucionais e tratamentos legislativos quanto ao direito à informação a respeito da natureza transgênica dos alimentos, como também ser analisado o princípio da precaução e a exigência dos estudos prévios de impacto ambiental e, igualmente pertinente, ponderar os aspectos relevantes no que se refere à rotulagem de produtos transgênicos.

\section{Direito à informação eficaz quanto à natureza transgênica dos produtos ofertados: apontamentos constitucionais e tratamentos legislativos}

Cabe ser apresentado o conteúdo sobre direito básico do consumidor à informação eficaz quanto à natureza transgênica dos produtos ofertados. Desse modo, aponta-se que o referido direito à informação, em sentido amplo, foi previsto durante a Conferência de Genebra em 1948, na Declaração Universal dos Direitos do Homem, a qual traz no artigo 19 que: "Toda pessoa tem direito à liberdade de opinião e expressão; este direito inclui a liberdade de, sem interferências, ter opiniões e de procurar, receber e transmitir informações e ideias por qualquer meio e independentemente de fronteiras" ${ }^{53}$. No mesmo sentido, observa-se que o princípio da informação, em sede internacional, constitui objeto do Princípio 10 da Declaração do Rio de Janeiro de $1992^{54}$, bem como foi adotado no Capítulo 40 da Agenda $21^{55}$.

Desta maneira, a nível internacional, verifica-se a importância com que é tratado o direito à informação a toda pessoa, por qualquer meio, o que é relevante, principalmente quanto a informações referentes aos efeitos perigosos que podem advir da adoção da

\footnotetext{
53 GENEBRA, 1948.

${ }^{54}$ ORGANIZAÇÃO DAS NAÇÕES UNIDAS, 1992.

${ }^{55}$ SENADO FEDERAL, 2001.
} 
tecnologia da modificação genética dos alimentos. Já a nível nacional, a previsão expressa do direito à informação encontra-se no artigo 5으, incisos XIV, XXXII e XXXIII, da Constituição Federal:

Art. 5 Todos são iguais perante a lei, sem distinção de qualquer natureza, garantindo-se aos brasileiros e aos estrangeiros residentes no País a inviolabilidade do direito à vida, à liberdade, à igualdade, à segurança e à propriedade, nos termos seguintes:

XIV- é assegurado a todos o acesso à informação e resguardado o sigilo da fonte, quando necessário ao exercício profissional;

XXXII- o Estado promoverá, na forma da lei, a defesa do consumidor;

XXXIII-todos têm direito a receber dos órgãos públicos informações de seu interesse particular, ou de interesse coletivo ou geral, que serão prestadas no prazo da lei, sob pena de responsabilidade, ressalvadas aquelas cujo sigilo seja imprescindível à segurança da sociedade e do Estado ${ }^{56}$.

Assim, percebe-se que o direito à informação se encontra no rol de direitos fundamentais, dessa forma:

[...] como direito fundamental, o direito à informação apresenta caráter tanto individual como coletivo, de modo que o sujeito ativo são todas as pessoas, físicas ou jurídicas. Também constitui direito subjetivo público e privado, podendo ser oponível ao sujeito passivo, Estado ou particular, que detém informação de interesse pessoal ou coletivo a alguém ${ }^{57}$.

Destarte, assevera-se que o referido acesso à informação é também assegurado pelo artigo 220, parágrafo 4ำ, da Constituição Federal, o qual se encontra esposado em nota explicativa ${ }^{58}$. Portanto, atenta-se que o acesso à informação, previsto constitucionalmente, deve ser amplo. Quando se tratar de informações de artefatos considerados de alta periculosidade, tal como os alimentos modificados geneticamente e os agrotóxicos, poderá ocorrer às devidas restrições à comercialização, tendo em vista a possível nocividade à saúde e ao meio ambiente. Do mesmo modo, estes produtos, nos termos da Constituição Federal, deveriam trazer nos invólucros as respectivas notificações resultantes de uso.

Nessa perspectiva, em sede consumerista, o Código de Defesa do Consumidor, nos artigos 60, incisos, I, II e III, 8o, parágrafo único e 31, que de igual forma se encontram transcritos, conforme nota específica ${ }^{59}$, preveem como direito básico do consumidor a proteção

\footnotetext{
56 BRASIL, 1988.

57 FERREIRA, 1997, p. 190-191.

58 Art. 220. A manifestação do pensamento, a criação, a expressão e a informação, sob qualquer forma, processo ou veículo não sofrerão qualquer restrição, observado o disposto nesta Constituição.

§ 4으 A propaganda comercial de tabaco, bebidas alcoólicas, agrotóxicos, medicamentos e terapias estará sujeita a restrições legais, nos termos do inciso II do parágrafo anterior, e conterá, sempre que necessário, advertência sobre os malefícios decorrentes de seu uso. BRASIL, 1988.

${ }^{59}$ Art. 6ㅇ - São direitos básicos do consumidor: I - a proteção da vida, saúde e segurança contra os riscos provocados por práticas no fornecimento de produtos e serviços considerados perigosos ou nocivos; II - a educação e divulgação sobre o consumo adequado dos produtos e serviços, asseguradas a liberdade de
} 
à vida, saúde e segurança quanto aos produtos e serviço danosos, a liberdade de escolha e o direito à informação adequada, clara, concisa e correta com as devidas especificações tal como as referentes à quantidade, característica, composição, qualidade e os prováveis riscos à saúde e segurança.

No mesmo sentido, impõe-se frisar, a previsão do artigo 4ํㅡ, caput e, principalmente, incisos I e VIII do Código de Defesa do Consumidor quando se referem aos objetivos da Política Nacional das Relações de Consumo, destacando-se, nestes pontos, a vulnerabilidade do consumidor e os estudos das variações do mercado de consumo.

Art. 4ํ A Política Nacional das Relações de Consumo tem por objetivo o atendimento das necessidades dos consumidores, o respeito à sua dignidade, saúde e segurança, a proteção de seus interesses econômicos, a melhoria da sua qualidade de vida, bem como a transparência e harmonia das relações de consumo, atendidos os seguintes princípios: I reconhecimento da vulnerabilidade do consumidor no mercado de consumo; VIII - estudo constante das modificações do mercado de consumo ${ }^{60}$.

Assim, é observado que a previsão acima citada, constante no Código de Defesa do Consumidor, se faz presente na seara dos organismos geneticamente modificados, tendo em vista que aos consumidores de OGMs deve ser garantido o respeitado à dignidade, à saúde e à segurança, como também a percepção da transparência nas relações de consumo.

Outrossim, explana Claudia Lima Marques que:

Na formação dos contratos entre consumidores e fornecedores o novo princípio básico norteador é aquele instituído pelo art. 4. o, caput, do CDC, o da transparência. A ideia central é possibilitar uma aproximação e uma relação contratual mais sincera e menos danosa entre consumidor e fornecedor. Transparência significa informação clara e correta sobre o produto a ser vendido, sobre o contrato a ser firmado, significa lealdade e respeito nas relações entre fornecedor e consumidor ${ }^{61}$.

\footnotetext{
escolha e a igualdade nas contratações; III - a informação adequada e clara sobre os diferentes produtos e serviços, com especificação correta de quantidade, características, composição, qualidade, tributos incidentes e preço, bem como sobre os riscos que apresentem; Art. $8^{\circ}$ Os produtos e serviços colocados no mercado de consumo não acarretarão riscos à saúde ou segurança dos consumidores, exceto os considerados normais e previsíveis em decorrência de sua natureza e fruição, obrigando-se os fornecedores, em qualquer hipótese, a dar as informações necessárias e adequadas a seu respeito. Parágrafo único. Em se tratando de produto industrial, ao fabricante cabe prestar as informações a que se refere este artigo, através de impressos apropriados que devam acompanhar o produto. Art. 31. A oferta e apresentação de produtos ou serviços devem assegurar informações corretas, claras, precisas, ostensivas e em língua portuguesa sobre suas características, qualidades, quantidade, composição, preço, garantia, prazos de validade e origem, entre outros dados, bem como sobre os riscos que apresentam à saúde e segurança dos consumidores. BRASIL, 1990.

60 BRASIL, 1990.

${ }^{61}$ MARQUES, 2002, p. 594-595.
} 
É pertinente ressaltar que o consumidor diante de produtos modificados geneticamente é considerado vulnerável, pois está diante de um alimento que oferece riscos incertos, cujas informações relevantes, que devem ser precisas e expressas, na grande maioria das vezes, encontram-se detidas nas mãos das empresas de biotecnologia. Dessa forma, podese dizer que "na sociedade atual é na informação que está o poder, a falta desta representa intrinsecamente um mínus, uma vulnerabilidade quanto mais importante for esta informação detida pelo outro" ${ }^{62}$.

Além disso, soma-se ao fator da retenção de informações primordiais, o desconhecimento, por parte dos consumidores, quanto ao processo de transferência genética entre espécies e os potenciais efeitos advindos desta manipulação, o que acentuam seguramente a vulnerabilidade dos consumidores de produtos transgênicos.

Em sede de sustentáculo ao que ora fora apresentado pelos autores supramencionados, impõem-se relevante reiterar o que está previsto na Constituição Federal bem como na legislação consumerista quanto ao direito à informação, destacando-se a relevância e vinculação ao tema, em espacial, no que tange aos organismos geneticamente modificados, uma vez que o fornecedor tem o dever de informar ao consumidor quanto aos possíveis efeitos que a ingestão destes alimentos possa vir acarretar. Por essas razões "o conteúdo da informação deve ser fiel e honesto, vedada a omissão de dados relevantes ou a utilização de informações falsas" ${ }^{63}$.

Impende ser referenciado que quanto à "liberação para cultivo de um produto geneticamente modificado no Brasil, o primeiro pedido nesse sentido foi formulado em 15 de junho de 1998, pela Monsanto do Brasil S.A. (empresa multinacional atuante na área de agricultura e biotecnologia) à CTNBio" ${ }^{64}$, com o objetivo de liberar para cultivo a soja Roundup Ready, a qual era capaz de resistir ao super herbicida Roundup. Aponta-se, porém, que os primeiros indícios de plantio ilegal de transgênicos - soja transgênica - ocorreu dois anos antes, em 1996, na Região Sul. Isto posto:

[...] para conseguir o referido OGM, os cientistas introduziram genes de várias espécies diferentes, a fim de que a planta adquirisse resistência ao agrotóxico glifosato da Monsanto na soja natural. Conseguiram assim desenvolver a soja resistente ao herbicida Roundup, que aplicado na plantação extermina as ervas daninhas e preserva a soja ${ }^{65}$.

\footnotetext{
62 BENJAMIN; MARQUES; BESSA, 2013, p. 106.

63 MALFATTI, 2003, p. 90.

64 MAIA, 2005, p. 19- 20.

65 LISBOA, 2005, p. 57.
} 
Portanto, diante da natureza transgênica dos produtos ofertados aos consumidores, sendo a soja Roundup Ready um grande marco e exemplo, observa-se a tamanha vulnerabilidade do consumidor quanto às diversas modificações genéticas que são realizadas nos alimentos que provenham de soja, alguns tipos de milho e de algodão, por exemplo. Assim, alimentos tidos como cotidianos, tal "como papinhas para crianças, salgadinhos e cereais matinais, óleos, bolachas e massas, margarinas e enlatados" ${ }^{\prime 66}$, deveriam conter informações quanto à porcentagem (se maior de 1\%) de transgenia que estes alimentos contêm e os efeitos que podem causar o consumo, nos rótulos.

O Decreto de Rotulagem de Transgênicos (Decreto 4.680/03) exige a informação sempre que o alimento contiver mais de $1 \%$ de ingrediente transgênico, mesmo que não seja possível detectá-lo por meio de testes de laboratório. A regra é: usou transgênico, tem que informar. E vale para todos os alimentos, sejam eles in natura ou processados. Mesmo os alimentos originários de animais alimentados com ração transgênica como leite, ovos, carnes - têm que ter um rótulo para avisar o consumidor com o símbolo " $T$ " 67 .

O Decreto 4.680/2003, já anteriormente referendado, regulamenta o direito à informação, nos termos da Lei no 8.078/90, quanto a alimentos produzidos a partir de organismos geneticamente modificados, segundo o que preconiza o artigo 2ำ68.

Já no que se refere à vulnerabilidade do consumidor, cita-se a previsão legal do artigo 4ำ do Código de Defesa do Consumidor que faz referência à Política Nacional das Relações de Consumo, os objetivos e o reconhecimento da vulnerabilidade dos consumidores no mercado consumerista.

Reputa-se relevante apontar que o direito à informação, relacionado à proteção ao meio ambiente, também se encontra assentado em dispositivos legais da Política Nacional do Meio Ambiente, Lei no 6.938/8170. Dessa forma, constata-se que a Política Nacional do Meio Ambiente prima pela garantia do direito à informação, principalmente por adotar como instrumento o sistema nacional de informações referentes a questões ambientais e a avaliação de impacto ambiental.

\footnotetext{
66 IDEC, 2010, p. 7.

67 IDEC, 2010, p. 8.

68 Art. 2o - Na comercialização de alimentos e ingredientes alimentares destinados ao consumo humano ou animal que contenham ou sejam produzidos a partir de organismos geneticamente modificados, com presença acima do limite de um por cento do produto, o consumidor deverá ser informado da natureza transgênica desse produto. BRASIL, 2003.

69 BRASIL, 1990.

70 BRASIL, 1981.
} 
No tocante à biossegurança, a Lei no 11.105/2005 no artigo 40 faz expressa menção em relação à aplicação do princípio da informação: "Os alimentos e ingredientes alimentares destinados ao consumo humano ou animal que contenham ou sejam produzidos a partir de OGM ou derivados deverão conter informação nesse sentido nos rótulos, conforme regulamento" 71 .

À vista do todo exposto, percebe-se que o direito à informação tem papel fundamental para dar conhecimento aos consumidores quanto ao que ingerem. Devendo-se, portanto, serem cumpridos requisitos, tal como clareza, precisão, completude, veracidade, compreensibilidade, adequação, necessidade e ostensividade das informações.

Diante disso, têm os consumidores o direito básico a conhecerem informações pontuais e fidedignas quanto aos alimentos adquiridos para consumo. Assim, de igual forma é crucial a utilização de signos e símbolos nos rótulos dos produtos que possam apresentar riscos aos consumidores, tal como artefatos provindos de organismos geneticamente modificados. Destaca-se como relevante que dadas informações devem sempre corresponder à verdade, para que assegure uma maior compreensão possível quantos os efeitos que podem ser ocasionados aos usuários destes alimentos, garantindo o direito à liberdade de escolha aos consumidores.

Isto posto, passa-se à abordagem quanto ao princípio da precaução, além da necessidade do estudo prévio de impacto ambiental, que conduzem a regulamentação dos produtos transgênicos, por intermédio das informações transmitidas por estudos científicos a respeito da adoção dos alimentos modificados geneticamente.

\section{A imprescindibilidade acerca da análise do princípio da precaução no que tange aos OGMS e a necessidade do estudo prévio de impacto ambiental}

Impõe-se dar continuidade a presente temática por meio de uma abordagem quanto aos princípios que norteiam a aprovação e comercialização de organismos geneticamente modificados.

Nesse desiderato, de início, merece análise o princípio da precaução, que norteia a discussão sobre biotecnologia e busca a renúncia de determinada tecnologia, caso desconhecido os efeitos ao ser humano e ao meio ambiente. Dessa forma, ao deparar-se com uma ciência de riscos incertos, é imprescindível a observância desde princípio.

\footnotetext{
${ }^{71}$ BRASIL, 2005.
} 
O princípio da precaução trata da imposição na tomada de providências acautelatórias relativas a atividades sobra as quais não haja uma certeza científica quanto aos possíveis efeitos negativos. [...] A precaução caracteriza-se pela ação antecipada diante do risco ou perigo desconhecido. [...] Envolve perigo abstrato ou potencial ${ }^{72}$.

Além disto, o princípio da precaução "ganhou consagração universal com a Declaração das Nações Unidas sobre Meio Ambiente e Desenvolvimento em 1992" 73, que no princípio 15, mencionado em nota de rodapé, vem assentar pontos imprescindíveis a despeito da observância deste princípio de fundamental relevância ${ }^{74}$.

Neste sentido, o Brasil, em 22 de fevereiro de 2004, submeteu-se, por adesão, ao Protocolo de Cartagena, que reafirma o enfoque da precaução estabelecido do Princípio 15 da Declaração do Rio, como pode ser percebido no artigo exposto a seguir, mais especificamente, artigo 1075 .

Deste modo, o princípio da precação "converteu-se em um dos pilares centrais do direito ambiental internacional, sendo incorporado também pelo ordenamento jurídico de diversos países, a exemplo do Brasil”76, previsto no artigo 225 e parágrafos da Constituição Federal, com destaque no parágrafo1으, incisos V e VII77 e no artigo 1으 da Lei № 11.105/2005 Lei de Biossegurança. Contudo, apenas como mero instrumento de orientação cabe transcrever:

Art. 10 Esta Lei estabelece normas de segurança e mecanismos de fiscalização sobre a construção, o cultivo, a produção, a manipulação, o transporte, a transferência, a importação, a exportação, o armazenamento, a pesquisa, a comercialização, o consumo, a liberação no meio ambiente e o descarte de organismos geneticamente modificados - OGM e seus derivados, tendo como diretrizes o estímulo ao avanço científico na área de biossegurança e biotecnologia, a proteção

\footnotetext{
72 MARCHESAN; STEIGLEDER; CAPPELLI, 2011, p. 51-52.

${ }^{73}$ FERREIRA, 2010, p. 141-142.

74 Princípio 15 da Declaração do Rio - Com o fim de proteger o meio ambiente, o princípio da precaução deverá ser amplamente observado pelos Estados, de acordo com suas capacidades. Quando houver ameaça de danos graves ou irreversíveis, a ausência de certeza científica absoluta não será utilizada como razão para o adiantamento de medidas economicamente viáveis para prevenir a degradação ambiental. ORGANIZAÇÃO DAS NAÇÕES UNIDAS, 1992.

75 Artigo 1ㅇ - De acordo com a abordagem de precaução contida no Princípio 15 da Declaração do Rio sobre Meio Ambiente e Desenvolvimento, o objetivo do presente Protocolo é de contribuir para assegurar um nível adequado de proteção no campo da transferência, da manipulação e do uso seguros dos organismos vivos modificados resultantes da biotecnologia moderna que possam ter efeitos adversos na conservação e no uso sustentável da diversidade biológica, levando em conta os riscos para a saúde humana, e enfocando especificamente os movimentos transfronteiriços. PROTOCOLO DE CARTAGENA, 2003.

76 FERREIRA, 2010, p. 142.

77 BRASIL, 1988.
} 
à vida e à saúde humana, animal e vegetal, e a observância do princípio da precaução para a proteção do meio ambiente (grifo nosso) ${ }^{78}$.

O princípio da precaução também foi adotado pela União Europeia, a qual reconheceu sua importância, de tal forma que figura nos tratados de Maastricht, Amsterdã e Nice ${ }^{79}$.

Entretanto, este princípio não vem sendo adotado pelos Estados Unidos, o qual segue outro princípio, qual seja, o da equivalência substancial, cujo "conceito surgiu no ano de 1993, em uma publicação da Organização para a Cooperação e o Desenvolvimento Econômico $(\mathrm{OCDE})^{\prime \prime 80}$. Tal princípio considera os produtos transgênicos como se fossem produtos equivalentes aos naturais, como se não acarretassem malefícios aos seres humanos. Todavia, este princípio não significa segurança aos consumidores.

O princípio da equivalência substancial é muito utilizado em estudos voltados a tratar de argumentos pró-transgênicos. Grandes empresas produtoras de OGMs, inclusive a Monsanto, utilizam-se do sobreposto princípio para que os produtos sejam comercializados sem maiores impedimentos.

Percebe-se, portanto, que em caso de não comprovação dos efeitos negativos ao ser humano, "favorece-se o produtor do benefício da dúvida" ${ }^{81}$, que poderá cultivar organismos geneticamente modificados, sem maiores empecilhos.

À vista disso, torna-se perceptível que, conforme aborda Zanini:

[...] os países favoráveis aos transgênicos, guiados pelo interesse de transnacionais detentoras de tecnologia, como é o caso dos Estados Unidos, seguem o princípio da equivalência substancial, enquanto os países contrários à liberação, como aqueles pertencentes à União Europeia, adotam o princípio da precaução ${ }^{82}$.

Dessa forma, reitera-se que o Brasil adotou o princípio da precaução, o que, porém não significa a busca por 0\% de efeitos negativos, uma vez que "o risco zero é uma utopia, pois sempre haverá um risco residual, que ainda é risco, que deve ser suportado pela coletividade ou pelos indivíduos" ${ }^{83}$. Todavia, devem ser preservadas condições dignas de vida, saúde e segurança alimentar à população. Prevalecendo, portanto, o respeito à dignidade humana sobre a busca de lucros e decisões meramente político-econômicas.

\footnotetext{
78 BRASIL, 2005.

${ }^{79}$ FROTA, 2002, p. 73.

80 VIEIRA, 2007, p. 112.

${ }^{81}$ VIEIRA, 2007, p. 113.

82 ZANINI, 2012, p.9.

83 LOPEZ, 2010, p. 31.
} 
Diante disso, percebe-se que é fundamental o estudo prévio de impacto ambiental, exigido nos termos do artigo 225, parágrafo1으, IV, da Constituição Federal ${ }^{84}$, que "propõe-se analisar a viabilidade ambiental de uma obra ou atividade através da avaliação dos possíveis riscos e impactos com potencial de causar significativa alteração das propriedades físicas, químicas e biológicas do meio ambiente" 85 .

O estudo prévio de impacto ambiental (EIA) se mostra necessário para avaliar determinada atividade que possa causar dano ao meio ambiente. Por meio deste estudo irá ocorrer à materialização do princípio da precaução. O EIA é considerado um documento técnico de avaliação dos impactos ambientais de determinadas atividades nocivas e, a partir deste estudo, é confeccionado o relatório de impacto ambiental (RIMA), o qual consiste em um documento gerencial que deve ser claro, objetivo e de fácil compreensão à população, de forma que assegure o direito fundamental à informação aos cidadãos.

Salienta-se que o estudo prévio de impacto ambiental "constitui pressuposto absolutamente necessário para o licenciamento de obras e atividades que possam causar significativa degradação do meio ambiente" ${ }^{\prime 66}$. Neste passo, destaca-se a exposição de Pacheco ${ }^{87}$ sobre a posição do CONSEA:

Com efeito, até hoje não foram cumpridas as exigências de realização de estudos de médio e longo prazo para se avaliar os potenciais efeitos adversos dos transgênicos sobre o meio ambiente e a saúde humana. A título de exemplo, cita-se um milho tolerante a glifosato que foi aprovado com base em dados oriundos de 68 liberações planejadas realizadas no país, sendo 6 para seleção de linhagens, 41 para avaliação agronômica e 21 campos de demonstração para agricultores, mas nenhum sobre impactos ambientais. Fiando-se nesses dados, e aceitando-os como suficientes, um grupo majoritário da CTNBio tem autorizado a liberação dessas plantas considerando que não há evidências de risco ambiental ou risco à saúde humana ou animal.

Aponta-se que a liberação para produção, comercialização e consumo de organismos transgênicos sem os devidos estudos sobre impactos ambientais pode representar potenciais ameaças tanto aos consumidores, assim como ao meio ambiente e a toda uma biodiversidade, sem deslembrar das futuras gerações, que sofrerão, inevitavelmente, consequências dessa postura atual. Por conseguinte, cita-se o que apresenta Nodari ${ }^{88}$ quanto à falta destes estudos:

\footnotetext{
${ }^{84}$ BRASIL, 1988.

${ }^{85}$ FERREIRA, 2010, p. 194.

${ }^{86}$ FERREIRA, 2010, p. 194.

87 CONSEA, 2014.

${ }^{88}$ NODARI, 2010, p. XVI.
} 
Apenas para exemplificar, no final de 2009, constatou-se que alguns organismos de solo (colêmbolas, nematoides, microartrópodos e macroartrópodos), responsáveis pelo desempenho de funções determinadas nas cadeias alimentares das quais fazem parte, apresentavam altas quantidades do transgene que proporciona a resistência da soja ao herbicida glifosato. Ou seja, está sendo disseminada em grande escala uma sequência de DNA cujos efeitos ainda são desconhecidos. O que vai acontecer ainda é uma incógnita. Portanto, a liberação desses organismos sem a realização de estudos a médio e longo prazos representa nada mais do que um descaso pelos interesses maiores da sociedade.

Neste sentido, nos termos da Lei no 11.105/2005, já reconhecida como a lei que disciplina o estudo da Biossegurança, cabe à CTNBio (Comissão Técnica Nacional de Biossegurança) analisar técnicas de biossegurança quanto aos organismos transgênicos, assim como também fornecer suporte para a implementação da Política Nacional de Biossegurança, o que até hoje nunca foi sequer discutida.

A lei também estabeleceu o Conselho Nacional de Biossegurança, que é formado por 11 (onze) ministros de Estado, porém, este permanece inerte quanto à implementação de orientações bem como quanto a exigibilidade dos devidos estudos prévios de impacto ambiental.

Nesta senda, aduz-se a respeito da necessidade de avaliação técnica conclusiva por parte do órgão avaliador. Nesse contexto:

Torna-se inevitável concluir que o órgão de avaliação técnica é o mesmo órgão responsável pelas decisões políticas sobre o uso da tecnologia. [...] Consequentemente, a CTNBio não recusou nenhum pedido de liberação comercial até hoje. A criação dessas facilidades para a indústria de organismos geneticamente modificados pode colocar em questão a independência do órgão, assim como o fato de divulgar em sua página institucional e favorecer a participação de seus membros em eventos promovidos por associações patrocinadas por multinacionais da biotecnologia ${ }^{89}$.

Estas empresas multinacionais utilizam-se da biotecnologia e modificam geneticamente sementes, tal como da soja, para que possam resistir à aplicação de herbicidas que estas mesmas produzem. Assim, c onsequentemente, terão o monopólio sobre o mercado, sendo que para evitar perturbações e oposições a respeito da questão ambiental, justificam que o que fabricam é pró-meio ambiente, ocultando-se os verdadeiros riscos à saúde e à vida de muitos indivíduos.

Diante do exposto, é de extrema importância que a implementação de organismos transgênicos não ocorra baseada somente em estudos encomendados por quem tem interesse

${ }^{89}$ CONSEA, 2014. 
na aprovação para o comércio e o cultivo de organismos geneticamente modificados, cita-se, por exemplo, estudos patrocinados por multinacionais que empregam a biotecnologia dos OGMs.

É oportuno considerar que o estudo prévio de impacto ambiental não tem efeito vinculante quanto à decisão do administrador público com relação ao licenciamento ambiental, contudo, continua sendo fundamental a exigibilidade, para que seja cumprido o dever de proteção ambiental e a preservação da vida em condições dignas de saúde e segurança às pessoas.

Neste seguimento, é substancial uma análise a respeito do retrocesso que representaria a alteração quanto à exigibilidade da rotulagem de produtos transgênicos, que acarretaria à desconsideração do direito fundamental à informação, garantido aos consumidores de alimentos modificados geneticamente.

\section{Rotulagem de produtos transgênicos: o retrocesso quanto à alteração da exigibilidade da rotulagem de produtos que contenham transgenia}

É de grande valia descrever que a exigência de rotulação e rastreamento dos produtos que contenham organismos geneticamente modificados está em consonância com o disposto nos artigos 9ำ, 10 e $66^{90}$ do Código de Defesa do Consumidor.

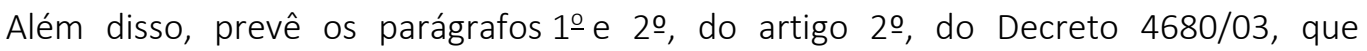
regulamenta o direito à informação quanto aos alimentos que contenham ou que sejam produzidos a partir de organismos geneticamente modificados:

\footnotetext{
${ }^{90}$ Art. 9 o $\mathrm{O}$ fornecedor de produtos e serviços potencialmente nocivos ou perigosos à saúde ou segurança deverá informar, de maneira ostensiva e adequada, a respeito da sua nocividade ou periculosidade, sem prejuízo da adoção de outras medidas cabíveis em cada caso concreto. Art. 10. O fornecedor não poderá colocar no mercado de consumo produto ou serviço que sabe ou deveria saber apresentar alto grau de nocividade ou periculosidade à saúde ou segurança. $\S 1^{\circ} \mathrm{O}$ fornecedor de produtos e serviços que, posteriormente à sua introdução no mercado de consumo, tiver conhecimento da periculosidade que apresentem, deverá comunicar o fato imediatamente às autoridades competentes e aos consumidores, mediante anúncios publicitários. § $2^{\circ}$ Os anúncios publicitários a que se refere o parágrafo anterior serão veiculados na imprensa, rádio e televisão, às expensas do fornecedor do produto ou serviço. $\S 3^{\circ} \mathrm{Sempre}$ que tiverem conhecimento de periculosidade de produtos ou serviços à saúde ou segurança dos consumidores, a União, os Estados, o Distrito Federal e os Municípios deverão informá-los a respeito. Art. 66. Fazer afirmação falsa ou enganosa, ou omitir informação relevante sobre a natureza, característica, qualidade, quantidade, segurança, desempenho, durabilidade, preço ou garantia de produtos ou serviços: Pena - Detenção de três meses a um ano e multa. $\S 1$ I Incorrerá nas mesmas penas quem patrocinar a oferta. § 2ㅇ Se o crime é culposo; Pena Detenção de um a seis meses ou multa. BRASIL, 1990.
} 
Art. $2^{\circ} \mathrm{Na}$ comercialização de alimentos e ingredientes alimentares destinados ao consumo humano ou animal que contenham ou sejam produzidos a partir de organismos geneticamente modificados, com presença acima do limite de um por cento do produto, o consumidor deverá ser informado da natureza transgênica desse produto.

$\S 1$ 으 Tanto nos produtos embalados como nos vendidos a granel ou in natura, o rótulo da embalagem ou do recipiente em que estão contidos deverá constar, em destaque, no painel principal e em conjunto com o símbolo a ser definido mediante ato do Ministério da Justiça, uma das seguintes expressões, dependendo do caso: "(nome do produto) transgênico", "contém (nome do ingrediente ou ingredientes) transgênico(s)" ou "produto produzido a partir de (nome do produto) transgênico".

$\S 2$ 2ㅇ consumidor deverá ser informado sobre a espécie doadora do gene no local reservado para a identificação dos ingredientes (com grifos no original) ${ }^{91}$.

Desta forma, a fim de facilitar a visualização ao consumidor, o rótulo deve apresentar o símbolo que indica a presença do transgênico, nos termos da Portaria 2.658/2003 ${ }^{92}$, do Ministério da Justiça. Este símbolo "consiste em um triângulo com a letra " $\mathrm{T}$ " no interior, com bordas e a letra na cor preta e o fundo interno na cor amarela" 93 . No entanto, a apresentação gráfica do símbolo transgênico nos rótulos a serem impressos em preto e branco terá a letra " $T$ " no interior com bordas e letra também de cor preta, porém, como o fundo branco.

\section{Figura 1- Apresentação gráfica do símbolo transgênico nos rótulos a serem impressos em policromia $(2003)^{94}$.}

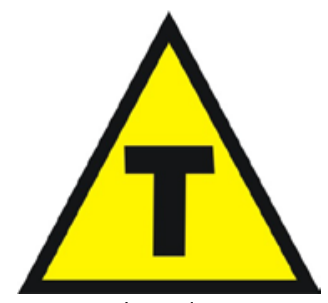

Fonte: Ministério da Justiça, 2003.

\footnotetext{
91 BRASIL, 2003.

923.3 - O símbolo deverá constar no painel principal, em destaque e em contraste de cores que assegure a correta visibilidade. 3.4 - O triângulo será equilátero. 3.5 - O padrão cromático do símbolo transgênico, na impressão em policromia, conforme apresentado no item 3.1, deve obedecer às seguintes proporções: 3.5.1 - Bordas do triângulo e letra T: 100\% Preto. 3.5.2 - Fundo interno do triângulo: 100\% Amarelo. 3.6 - A tipologia utilizada para grafia da letra T deverá ser baseada na família de tipos "Frutiger", bold, em caixa alta, conforme apresentada no item 3.1. 4. DIMENSÕES MíNIMAS: 4.1 - A área a ser ocupada pelo símbolo transgênico deve representar, no mínimo, 0,4\% (zero vírgula quatro por cento) da área do painel principal, não podendo ser inferior a 10,82531mm2 (ou triângulo com laterais equivalentes a $5 \mathrm{~mm}$ ). 4.2 O símbolo transgênico deverá ser empregado mantendo-se, em toda a sua volta, uma área livre equivalente a, no mínimo, a área da circunferência que circunscreve o triângulo, passando pelos três vértices e com centro no circuncentro. MINISTÉRIO DA JUSTIÇA, 2003.

93 ZANINI, 2012, p. 11.

${ }^{94}$ MINISTÉRIO DA JUSTIÇA, 2003.
} 
Deste modo, observa-se que dada simbologia serve para demonstrar a periculosidade do que se consome. Porém, gerou-se forte oposição às exigências legais da comercialização de alimentos transgênicos, assim, determinados congressistas propõem iniciativas no intuito de alterar a legislação, que trata a questão da rotulagem de produtos que contenham organismos geneticamente modificados.

Nesta perspectiva, cita-se o Projeto de Lei no 4.148/2008 ${ }^{95}$, atualmente retornado em pauta de discussões sob a rubrica de PLC n.o 34/2015, cuja autoria é do deputado federal Luiz Carlos Heinze, que tem a finalidade de alterar a previsão do artigo 40 da Lei de Biossegurança.

O PL do Deputado Luis Carlos Heinze: (1) não torna obrigatória a informação sobre a presença de transgênico no rótulo se não for possível sua deteç̧ão pelos métodos laboratoriais, o que exclui a maioria dos alimentos (como papinhas de bebês, óleos, bolachas, margarinas); (2) não obriga a rotulagem dos alimentos de origem animal alimentados com ração transgênica; (3) exclui o símbolo $T$ que hoje permite a fácil identificação da origem transgênica do alimento (como tem se observado nos óleos de soja); e (4) não obriga a informação quanto à espécie doadora do gene ${ }^{96}$.

Com isso, observa-se que a rotulação somente será necessária quando detectável a presença de organismos geneticamente modificados no produto final. "Dessa forma, se eventualmente forem aprovados, teremos como resultado a mudança de paradigma da legislação, que passará do critério da rastreabilidade, também adotado na União Europeia, para o critério da detectabilidade" ${ }^{\prime 97}$.

Assim, destaca-se que:

Na prática, o projeto revoga o Decreto 4.680/03, que já regulamenta o assunto. A redação do projeto deixa de lado a necessidade, imposta pelo decreto, de o consumidor ser informado sobre a espécie doadora do gene no local reservado para a identificação dos ingredientes. A informação escrita sobre a presença de transgênicos deverá atender ao tamanho mínimo da letra definido no Regulamento Técnico de Rotulagem Geral de Alimentos Embalados, que é de $1 \mathrm{~mm}^{98}$.

Salienta-se que este projeto foi aprovado na Câmara dos Deputados, no dia 28 de abril de 2015, com 320 (trezentos e vinte) votos favoráveis a 135 (cento e trinta e cinco) contrários, o qual seguiu para votação pelo Senado Federal ${ }^{99}$.

Sendo assim, registra-se:

\footnotetext{
${ }^{95}$ BRASIL, 2008.

${ }^{96}$ ABRASCO et. al, 2015.

${ }^{97}$ ZANINI, 2012, p.11.

${ }^{98}$ CÂMARA DOS DEPUTADOS, 2015.

${ }^{99}$ CÂMARA DOS DEPUTADOS, 2015.
} 
[...] que o PL n.o 4.148/2008 desconsidera a vontade da maioria da população brasileira. Primeiro, porque, segundo enquete pública realizada pelo Senado Federal, 94\% dos participantes possuem opinião contrária à referida proposição legislativa. Segundo, porque outras pesquisas de opinião oficiais demonstram a vontade da maioria da sociedade em "querer saber se um alimento contém ou não ingrediente transgênico (74\% da população IBOPE, 2001; 71\% IBOPE, 2002; 74\% IBOPE, 2003; e 70,6\% ISER, 2005)", como informa a Carta das entidades da sociedade civil contra o PL 4148/2008 (com grifos no original) ${ }^{100}$.

Diante desta problemática, embora o objetivo deste artigo não seja realizar análise jurisprudencial, é de grande monta destacar a recente decisão do Supremo Tribunal Federal, proferida no dia 12 de maio de 2016, que preservou o direito à informação aos consumidores no que tange os transgênicos.

O Instituto Brasileiro de Defesa do Consumidor (IDEC) e o Ministério Público Federal do Distrito Federal (MPF/DF), no ano de 2001, haviam apresentado Ação Civil Pública, de número 2001.34.00.022280-6/DF, em face da União para exigir a rotulagem de produtos transgênicos, independentemente de percentual de transgenia ou qualquer outra restrição e requereu a fiscalização por parte da União a fim de que fossem recolhidos os produtos que desobedecessem ao critério da rotulagem. Em 24 de outubro de 2007, foi proferida sentença, pelo Juízo da 13a Vara Federal da Seção Judiciária do Distrito Federal, favorável ao IDEC e ao MPF/DF, determinando que os produtos transgênicos fossem rotulados independentemente do percentual de transgenia que contivessem ${ }^{101}$.

Porém, a União e a Associação Brasileira da Indústria de Alimentos entraram com recurso no Tribunal Regional Federal da 1ạ Região, o qual fora rejeitado, em 2009, sendo mantido o teor da sentença. Dessa forma, a União e a Abia recorreram ao STF. Assim, no dia 17 de dezembro de 2012, foi deferido o pedido de liminar para suspender o feito até o julgamento do mérito, que ocorreu neste ano de 2016, pelo ministro Edson Fachin ${ }^{102}$.

O ministro Edson Fachin manteve a decisão obtida pelo Idec e voltou a garantir a indicação no rótulo de alimentos que utilizam ingredientes geneticamente modificados, independentemente da quantidade presente. A exigência estava suspensa desde 2012, por uma decisão liminar (provisória) do ministro Ricardo Lewandovski, do STF, que atendeu ao pedido da União e da Associação Brasileira de Indústria de Alimentos (Abia) contra a decisão do Tribunal Regional Federal da Primeira Região (TRF-1), que foi favorável à ação do Idec. A União e Abia alegavam que a decisão do TRF-1 "usurpava a competência" do STF de

\footnotetext{
${ }^{100}$ INSTITUTO BRASILEIRO DE DEFESA DO CONSUMIDOR - IDEC; INSTITUTO SOCIOAMBIENTAL - ISA; MOVIMENTO DOS PEQUENOS AGRICULTORES - MPA; TERRA DE DIREITOS, 2015, p. 6-7.

101 IDEC, 2016.

102 IDEC, 2016.
} 
decidir sobre o tema. Mas, ao julgar o recurso, Fachin não concordou. Em decisão monocrática (analisada apenas por um julgador), o ministro relator do processo validou a decisão do Tribunal. A decisão do TRF-1 que voltou a valer acolhe o pedido do Idec de rotulagem de qualquer teor de transgênicos e afasta a aplicação do Decreto $n^{\circ} 4.680 / 03$, que flexibiliza a exigência de rotulagem apenas para produtos que contêm mais de $1 \%$ de ingredientes geneticamente modificados. O Tribunal considerou que $\mathrm{O}$ direito à informação previsto no Código de Defesa do Consumidor (CDC) se sobrepõe ao decreto (com grifos no original) ${ }^{103}$.

Assim, trata-se de uma grande conquista esta respeitável e renomada decisão, pois garante que os produtos transgênicos devam ser rotulados, salvaguardando, dessa forma, o direito fundamental e básico à informação aos consumidores independentemente da porcentagem de transgenia dos produtos, bem como acaba por minorar o ímpeto à aprovação do sobredito Projeto de Lei 4.148/2008. "A União e a Abia, ainda, podem entrar com novo recurso para que o tema seja analisado pelo plenário do STF. Mas, por hora, o direito à informação venceu mais uma vez" ${ }^{104}$.

É de clara percepção que as alterações pretendidas pelo Projeto de Lei ํo 4.148/2008 acarretará violações ao direito básico fundamental à informação, por isso o consumidor será ludibriado quanto à presença ou não de organismos geneticamente modificados nos produtos que adquire e consome diariamente. Ressalta-se, portanto, que este projeto foi repudiado na Carta das entidades da sociedade civil ${ }^{105}$, pela $\mathrm{OAB} / \mathrm{RJ}^{106}$, dentre outras empresas e organizações, além de ser contrário ao resultado de diversas pesquisas de opinião, acima referidas, que demonstraram a rejeição das alterações constantes no Projeto de Lei $4.148 / 2008$.

Isto posto, resta demonstrado que a alteração quanto à rotulagem de produtos que contenham ou provenham de organismos geneticamente modificados representa um retrocesso, neste sentido, esta proposta só traria benefícios às grandes empresas multinacionais do setor agrícola que comercializam sementes transgênicas.

Portanto, em uma síntese prévia, ousa-se referendar a necessidade de rejeição integral do Projeto de Lei 4.148/2008, a fim de que seja preservado o direito fundamental do consumidor à informação. Desse modo, aguarda-se a votação no Senado Federal, na expectativa de que seja arquivado dado projeto.

\footnotetext{
103 IDEC, 2016.

104 IDEC, 2016.

105 ABRASCO et. al, 2015.

106 OAB/RJ, 2015.
} 


\section{CONCLUSÃO}

Conforme demonstrado no desenvolvimento do presente artigo, os organismos geneticamente modificados refletem um avanço genético-tecnológico revolucionário, porém, o que resta evidenciado é que os cultivos transgênicos foram implementados de forma prematura cientificamente, tendo em vista que ainda não é sabido, a priori, os efeitos suscetíveis do consumo de alimentos modificados geneticamente, considerando-se que os danos podem variar a depender do período de tempo e da quantidade ingerida.

Assim, observou-se uma estreita e direta relação entre uma maior probabilidade de efeitos nocivos quanto mais variedades de alimentos modificados geneticamente forem introduzidas no mercado de consumo.

Neste sentido, pode ser concluído que os alimentos modificados geneticamente não são seguros e a ciência ainda não está preparada para efetuar uma manipulação genética de forma transparente e fidedigna no sentido de proporcionar um avanço à saúde e à alimentação humana, assim como, também, ao meio ambiente. Por isso, mostra-se necessário a efetivação de estudos científicos longitudinais.

O tratamento atual, no mercado de consumo, dos organismos geneticamente modificados como confiáveis e ausentes de risco não é sensato e nem comedido, além de demonstrar uma afronta ao direito à informação eficaz aos consumidores de alimentos transgênicos.

Deste modo, é relevante que os consumidores exijam que a rotulagem de produtos transgênicos seja obrigatória, a fim de não ser suprimida por projetos de lei que se mostram em prol dos interesses comerciais e econômicos, os quais se utilizam de argumentos falaciosos, frutos de uma realidade fabricada pelas empresas de biotecnologia.

Isto posto, devem os cidadãos prezar por qualidade de vida, de saúde e do meio ambiente, por meio do consumo de alimentos orgânicos e produtos que são rotulados como não transgênicos, pela adoção de guias de compras que identificam determinadas marcas de produtos modificados geneticamente, as quais se encontram disponíveis na internet, assim como também por meio da exigência de rotulagem obrigatória dos produtos transgênicos. Demonstra-se, desta maneira, a contrariedade aos projetos de lei que buscam boicotar uma transparência na relação de consumo de alimentos modificados geneticamente.

Dessa forma, deve-se lutar contra as aprovações de fachada, que não conseguem identificar os riscos que os seres humanos, animais e meio ambiente estão expostos e ainda 
desconsideram o consagrado princípio da precaução, difundido mundialmente, bem como inobservam o imprescindível estudo prévio de impacto ambiental.

Portanto, o direito básico fundamental à informação - já devidamente exposto no decorrer da pesquisa, previsto tanto internacionalmente como também no âmbito interno da Constituição Federal, no Código de Defesa do Consumidor e demais leis esparsas, deve ser respeitado e garantido a todos os indivíduos, de forma que os produtos geneticamente modificados não firam as garantias essenciais à sociedade, tal como saúde, alimentação, segurança alimentar e meio ambiente ecologicamente equilibrado.

Destarte, mostra-se necessário cientificamente uma espécie de moratória prolongada, no sentido de que não seja levada adiante a manipulação genética feita pela indústria de biotecnologia enquanto se estiver diante de expressivas incertezas científicas quanto às consequências causadas pelo consumo de alimentos transgênicos e se esteja na presença, não raramente, de informações preparadas pela indústria e anúncios comerciais ardilosos, que buscam ludibriar o agricultor e, assim, aumentar a quantidade de agrotóxicos- venenos agrícolas- na alimentação.

À vista disso, a população deve insurgir contra a manipulação realizada pela indústria com o conluio político, no intuito de controlar o mercado de sementes e, consequentemente, efetuar o controle sobre a alimentação dos indivíduos.

Deve-se atentar, primordialmente, pelo interesse dos consumidores e não pelos interesses financeiros. Assim sendo, em sede de linhas conclusivas, merece ser evidenciado que o presente artigo não visa demonstrar a contrariedade à engenharia genética como ciência, nem o uso para a produção de medicamentos e estudo do DNA. O que se intentou, com a presente pesquisa, é perscrutar quanto ao direito à informação e a consequente rotulagem, a qual se mostra essencial, não só por questões de saúde, mas por se entender que as pessoas têm o direito de fazerem escolhas, possibilidade esta que as indústrias de biotecnologia se mostram contrárias, devido ao receio de que, com uma ampla informação aos consumidores, haja uma diminuição da compra e consumo de produtos transgênicos.

Em linhas de desfecho, averiguou-se que o ser humano e o meio ambiente não podem continuar reféns dos efeitos colaterais imprevisíveis, todos eles já de forma mais exaustiva possível, descritos na construção do próprio artigo, corroborado pela concepção de que inevitavelmente estão imbricados com o consumo e cultivo de OGMs, que não estão sendo avaliados, adequadamente, pela CTN-Bio. A aprovação e consumo de organismos geneticamente modificados, dessa forma, é extremamente irresponsável e perigosa. 


\section{REFERÊNCIAS}

ABRASCO - ASSOCIAÇÃO BRASILEIRA DE SAÚDE COLETIVA. et al.

Carta das entidades da sociedade civil contra o PL 4148/2008, que prevê acabar com a rotulagem dos transgênicos. Disponível em: <http://www.idec.org.br/pdf/carta-rotulagemtransgenicos.pdf>. Acesso em: 04 nov. 2015.

AYALA, Patrick de Araújo. Deveres de proteção e o direito fundamental a ser protegido em face dos riscos associados aos alimentos transgênicos. 2009. Tese. (Programa de Pós-Graduação em Direito - Doutorado) - Universidade Federal de Santa Catarina, Florianópolis, 2009.

BENBROOK, Charles. Genetically Engineered Crops and Pesticide Use in the United States: The First Nine Years. New York: BioTech InfoNet - Technical Paper Number, 2004.

BENJAMIN, Antônio Herman V.; MARQUES, Claudia Lima; BESSA, Leonardo Roscoe. Manual de Direito do Consumidor. 5 ed. Revista, Atualizada e ampliada. São Paulo: Revista dos Tribunais, 2013.

BRASIL. Constituição da República Federativa do Brasil de 1988. Dispõe sobre Constituição Federal. $1988 . \quad$ Disponível em: <http://www.planalto.gov.br/ccivil_03/constituicao/constituicao.htm>. Acesso em: 09 jul. 2015.

Decreto no 4.680, de 24 de abril de 2003. Dispõe sobre o direito à informação quanto aos alimentos destinados ao consumo produzidos a partir de organismos geneticamente modificados. Disponível em: <http://www.planalto.gov.br/ccivil_03/decreto/2003/d4680.htm>. Acesso em: 04 nov. 2015.

Lei no 6.938, de 31 de agosto de 1981.Dispõe sobre a Política Nacional do Meio Ambiente. Disponível em: <http://www.planalto.gov.br/ccivil_03/Leis/L6938.htm>. Acesso em: 04 nov. 2015.

Lei no 8.078 de 11 de setembro de 1990. Dispõe sobre Código de Defesa do Consumidor. Disponível em: <http://www.planalto.gov.br/ccivil_03/leis/l8078.htm>. Acesso em: 09 jul. 2015.

Lei no 8.974 de 05 de janeiro de 1995. Antiga lei que dispunha sobre a biossegurança, revogada e substituída pela Lei 11.105/2005.Disponível em: <http://www.planalto.gov.br/ccivil_03/LEIS/L8974.htm>. Acesso em: 21 nov. 2015.

Lei no 10.688 de 13 de junho de 2003. Dispõe sobre normas para a comercialização da produção de soja da safra de 2003. Disponível em: <http://www.planalto.gov.br/ccivil_03/leis/2003/L10.688.htm>. Acesso em: 20 mai. 2015.

Lei no 10.814 de 15 de dezembro de 2003. Dispõe sobre normas para o plantio e comercialização da produção de soja geneticamente modificada da safra de 2004. Disponível em: <http://www.planalto.gov.br/ccivil_03/leis/2003/L10.814.htm>. Acesso em: 20 mai. 2015.

Lei no 11.105 de 24 de março de 2005. Dispõe sobre Biossegurança. Disponível em: <http://www.planalto.gov.br/ccivil_03/_ato2004-2006/2005/lei//11105.htm>. Acesso em: 20 mai. 2015.

Lei 11.460, de 21 de março de 2007. Dispõe sobre o plantio de organismos geneticamente modificados em unidades de conservação. Disponível em: <http://www.planalto.gov.br/ccivil_03/_Ato2007-2010/2007/Lei/L11460.htm>. Acesso em: 16 abr. 2016.

Projeto Lei 4.148/2008. Altera e acresce dispositivos à Lei $n^{\circ} 11.105$, de 24 de março de

Disponível 
em:<http://www.camara.gov.br/proposicoesWeb/prop_mostrarintegra?codteor=605180 $>$. Acesso em: 04 nov. 2015.

CÂMARA DOS DEPUTADOS. Aprovado projeto que dispensa símbolo da transgenia em rótulos de produtos.

<http://www2.camara.leg.br/camaranoticias/noticias/CONSUMIDOR/486822-APROVADOPROJETO-QUE-DISPENSA-SIMBOLO-DA-TRANSGENIA-EM-ROTULOS-DE-PRODUTOS.html>. Acesso em: 04 nov. 2015.

CARMAN, Judy. Is GM Food Safe to Eat?. In: HINDMARSH, R.; LAWRENCE, G. Recording Nature Critical Perspectives on Genetic Engineering. Sidney: UNSW Press, 2004.

CARNEIRO, Fernando Ferreira; AUGUSTO, Lia Giraldo da Silva; RIGOTTO, Raquel Maria; FRIEDRICH, Karen; BÚRIGO, André Campos. Dossiê ABRASCO: um alerta sobre os impactos dos agrotóxicos na saúde. Rio de Janeiro/São Paulo: Escola Politécnica de Saúde Joaquim Venâncio/Expressão Popular, 2015, p. 112-113. Disponível em: < http://www.abrasco.org.br/dossieagrotoxicos/wpcontent/uploads/2013/10/DossieAbrasco_2015_web.pdf >. Acesso em: 04 nov. 2015.

CONSEA. Exposição de Motivos no 002, 2014. Dispõe à presidenta da República sobre os problemas e desafios dos organismos geneticamente modificados. Disponível em: <http://www.mmcbrasil.com.br/site/materiais/download/2014-em002-maio-transgenicos.pdf>. Acesso em: 29 ago. 2015.

DASGUPTA, R.; GARCIA II, B. H.; GOODMAN, R. M.. Systemic spread of an RNA insect virus in plants expressing plant viral movement protein genes. New York: Proc Nat Acad Sci USA, 2001.

DUGGAN, Paula S. et al. Fate of genetically modified maize DNA in the oral cavity and rumen of sheep. London: British Journal of Nutrition, 2003.

FERREIRA, Aluízio. Direito à informação, direito à comunicação: direitos fundamentais na Constituição brasileira. São Paulo: Celso Bastos, 1997.

FERREIRA, Heline Sivini. Desvendando os organismos transgênicos: as interferências da sociedade de risco no estado de direito ambiental brasileiro. Rio de Janeiro: Forense Universitária, 2010.

FREESE, William; SCHUBERT, David. Safety Testing and Regulation of Genetically Engineered Foods. Washington: Biotechnology and Genetic Engineering Reviews, 2004.

FROTA, Mário. Segurança alimentar - imperativo de cidadania. Revista de Direito do Consumidor, São Paulo, n. 44, 2002.

FWW, Food \& Water Watch. Under the Influence: the National Research Council and GMOs. Disponível em: <http://www.foodandwaterwatch.org/sites/default/files/ib_1605_nrcinfluencefinal-web_0.pdf>. Acesso em: 07 jun. 2016. 
GENEBRA. Declaração Universal dos Direitos do Homem. 1948. Disponível em: <http://www.ohchr.org/EN/UDHR/Documents/UDHR_Translations/por.pdf>. Acesso em: 03 nov. 2015.

GRUPO DE CIÊNCIA INDEPENDENTE. Em defesa de um mundo sustentável sem transgênicos. São Paulo: Expressão Popular, 2004.

GUPTA, Ashish et al. Impact of Bt Cotton on Farmer's Health. India: Investigation Report, 2005.

GURAYA, S. S.. Biology of Spermatogenesis and Spermatozoa in Mammals. London: Springer Verlag, 1987.

IDEC. Cartilha transgênicos: feche a boca e abra os olhos, 2010.

Vitória: STF garante rotulagem de qualquer teor de transgênicos, fruto de ação do Idec. Disponível em: <http://www.idec.org.br/em-acao/em-foco/vitoria-stf-garante-rotulagem-dequalquer-teor-de-transgenicos-fruto-de-aco-do-idec>. Acesso em: 30 mai. 2016.

INSTITUTO BRASILEIRO DE DEFESA DO CONSUMIDOR - IDEC; INSTITUTO SOCIOAMBIENTAL ISA; MOVIMENTO DOS PEQUENOS AGRICULTORES - MPA; TERRA DE DIREITOS. PARECER. Nota técnico-jurídica sobre o projeto de lei n. 4.148/2008 (PLC n.o 34/2015): rotulagem de transgênicos. Disponível em: <http://terradedireitos.org.br/wpcontent/uploads/2015/07/parecer.pdf>. Acesso em: 04 nov. 2015.

LEITE, José Rubens Morato; AYALA, Patryck de Araújo. Direito ambiental na sociedade de risco. 2. ed. Rio de Janeiro: Forense Universitária, 2004.

LEWIS, Ricki. The Rise of Antibiotic - Resistant Infections. New York: FDA Consumer Magazine, 1995.

LISBOA, Marijane. Transgênicos no Brasil: o descarte da opinião pública. In: DERANI, Cristiane (Org.). Transgênicos no Brasil e Biossegurança. Porto Alegre: Sergio Antonio Fabris, 2005.

LOPEZ, Teresa Ancona. Princípio da precaução e evolução da responsabilidade civil. São Paulo: Quartier Latin, 2010.

MAIA, Cleusa Aparecida da Costa. Organismos geneticamente modificados: violação a direitos fundamentais. Revista Imes Direito, São Caetano do Sul, ano VI, n. 11,jul./dez. 2005.

MALFATTI, Alexandre David. O direito de informação no Código de Defesa do Consumidor. São Paulo: Alfabeto Jurídico, 2003.

MALATESTA, M. et al. Ultrastructural Morphometrical and Immunocytochemical Analyses of Hepatocyte Nuclei from Mice Fed on Genetically Modified Soybean - Cell Struct Funct. Rome: NCBI, 2002.

MARCHESAN, Ana Maria Moreira; STEIGLEDER, Annelise Monteiro; CAPPELLI, Sílvia. Direito ambiental. Porto Alegre: Verbo Jurídico, 2011. 
MARKAVERICH, Barry M. et al. Leukotoxin Diols from Ground Corncob Bedding Disrupt Estrous Cyclicity in and Stimulate MCF-7 Breast Cancer Cell Proliferation. Environmental Health Perspectives, New York, vol. 113, n. 12, dez.2005

MARQUES, Cláudia Lima. Contratos no Código de Defesa do Consumidor - O novo regime das relações contratuais. 4. ed. Revista, Atualizada e ampliada. São Paulo: Revista dos Tribunais, 2002.

MINISTÉRIO DA JUSTIÇA. Portaria no 2.658, de 22 de dezembro de 2003. Dispõe sobre a definição do símbolo de que trata o art. 2으, § 10, do Decreto 4.680, de 24 de abril de 2003. Disponível em: <http://portal.anvisa.gov.br/wps/wcm/connect/1e3d43804ac0319e9644bfa337abae9d/Portari a_2685_de_22_de_dezembro_de_2003.pdf?MOD=AJPERES>. Acesso em: 15 mai. 2016.

NATIONAL ACADEMIES OF SCIENCES, ENGINEERING, AND MEDICINE. Genetically Engineered Crops: Experiences and Prospects. Washington: The National Academies Press, 2016. Disponível em: < https://drive.google.com/file/d/OB-pJR4cGo9ckQ2Nod09ISW55dDA/view?pref=2\&pli=1>. Acesso em: 10 set. 2017.

NODARI, Rubens Onofre. Prefácio. In: FERREIRA, Heline Sivini. Desvendando os organismos transgênicos: as interferências da sociedade de risco no estado de direito ambiental brasileiro. Rio de Janeiro: Forense Universitária, 2010.

NUNES, Ana Carolina. Europa diz não aos transgênicos. Revista Isto É, n. 2393, São Paulo, 09 out. 2015. Disponível em: <http://istoe.com.br/438343_EUROPA+DIZ+NAO+AOS+TRANSGENICOS/>. Acesso em: 09 set. 2016.

OAB/RJ. Transgênicos: OAB/RJ repudia PL que restringe rotulagem de produtos. Disponível em: $<$ http://www.oabrj.org.br/noticia/90845-transgenicos-oabrj-repudia-pl-que-restringerotulagem-de-produtos->. Acesso em: 04 nov. 2015.

ORGANIZAÇÃO DAS NAÇÕES UNIDAS. Conferência das Nações Unidas sobre Meio Ambiente e Desenvolvimento, Declaração do Rio sobre Meio Ambiente e Desenvolvimento. 1992. Dispõe sobre uma nova e justa parceria global mediante a criação de novos níveis de cooperação entre os Estados, os setores-chaves da sociedade e os indivíduos, trabalhando com vistas à conclusão de acordos internacionais que respeitem os interesses de todos e protejam a integridade do sistema global de meio ambiente e desenvolvimento, reconhecendo a natureza integral e interdependente da Terra. Disponível em: <http://www.onu.org.br/rio20/img/2012/01/rio92.pdf>. Acesso em: 02 nov. 2015.

PRESCOTT, V. E. et al. Transgenic Expression of Bean r-Amylase Inhibitor in Peas Results in Altered Structure and Immunogenicity. Cincinnati: Journal of Agricultural Food Chemistry, 2005.

PROTOCOLO DE CARTAGENA. Dispõe sobre biossegurança da convenção sobre diversidade biológica. 2003. Disponível em: <http://www.mma.gov.br/port/sdi/ea/documentos/convs/prot_biosseguranca.pdf>. Acesso em: 02 nov. 2015. 
PRUPIS, Nadia. Transgênicos: Mais uma trapaça. Tradução Gilberto Schittini. Disponível em: $<$ http://outraspalavras.net/posts/transgenicos-mais-uma-trapaca/>. Acesso em: 07 jun. 2016.

ROBIN, Marie- Monique. Arte TV. PARIS, 11 de Março de 2008. O Mundo Segundo a Monsanto. Disponível em: <https://www.youtube.com/watch?v=y6leaqoN6Ys>. Acesso em: 10 maio 2016.

SENADO FEDERAL. Agenda 21 - Conferência das Nações Unidas sobre Meio Ambiente e Desenvolvimento. 3. ed. Brasília: Senado Federal, Subsecretaria de Edições, 2001.

SHIVA, Vandana. Monoculturas da mente: perspectivas da biodiversidade e da biotecnologia. Tradução de Dinah de Abreu Azevedo. São Paulo, Gaia, 2003.

SMITH, Jeffrey M. Roleta Genética: riscos documentados dos alimentos transgênicos sobre a saúde. São Paulo: João de Barro, 2009.

STEINBRECHER, Ricarda A.. Risks associated with ingestion of Chardon LL maize - The reversal of $\mathrm{N}$ - acetyl- $\mathrm{L}$ - glufosinate to the active herbicide $\mathrm{L}$ - glufosinate in the gut of animals. London: Chardon LL Hearing, 2002.

VIEIRA, David Laerte. Princípio da precaução versus princípio da equivalência substancial e a polêmica em torno da liberação dos transgênicos no Brasil. Interesse Público, Belo Horizonte, v. 9, n. 41, jan. 2007.

ZANINI, Leonardo Estevam de Assis. Os direitos do consumidor e os organismos geneticamente modificados. Revista de Doutrina da 4a Região, Porto Alegre, n. 48, jun. 2012. Disponível em: <http://www.revistadoutrina.trf4.jus.br/artigos/edicao048/Leonardo_Zanini.html> Acesso em: 01 jun. 2015.

Trabalho enviado em 15 de junho de 2017.

Aceito em 19 de outubro de 2017. 